\title{
Strategy for detection and identification of bacteria based on 16S rRNA genes in suspected cases of Whipple's disease
}

\author{
C. DAUGA, I. MIRAS and P. A. D. GRIMONT \\ Unité des Entérobactéries, Unité 389 INSERM, Institut Pasteur, F-75724 Paris, Cedex 15. France
}

\begin{abstract}
The 16S ribosomal RNA (rRNA) gene of the phylogenetic subdivision containing grampositive bacteria with a high $G+C$ content was detected specifically in clinical specimens from patients suspected of having Whipple's disease. The primary structure of $16 \mathrm{~S}$ rDNA amplified from clinical samples was determined by cloning and sequencing. Two sorts of sequences were identified: one corresponded exactly to the rRNA sequence of Tropheryma whippelii (GenBank accession no. M87484) while the other was related to that of members of the genus Corynebacterium. No sequence related to Mycobacterium spp. or Rhodococcus equi was observed. Exhaustive examination of negative specimens with broad-range eubacterial primers detected one sequence related to Enterobacteriaceae and another related to Enterococcus spp. To speed identification of $T$. whippelii, a nested amplification method was devised. A first amplification specific for the grampositive bacteria subdivision was performed, followed by a second amplification with T. whippelii-specific primers. The amplified $T$. whippelii product was checked by digestion with Ava II, Stu I, and PstI endonucleases. These techniques were applied to DNA extracted from seven intestinal biopsy samples, two cerebrospinal fluid samples and one articular fluid from patients suspected of having Whipple's disease. $T$. whippelii 16S rDNA was found in two of the biopsy samples, one of the cerebrospinal fluid samples and in the articular fluid.
\end{abstract}

\section{Introduction}

Whipple's disease, defined initially as an 'intestinal lipodistrophy' of the small intestine, is rare, with only 617 cases reported in the world between 1907 and 1986 [1]. The most common clinical presentation is a malabsorption syndrome with diarrhoea, weight loss and abdominal pain. Migratory arthritis or severe arthralgia often occur for years before diarrhoea develops. The disease is also associated with fever, lymphadenopathy, anaemia and cardiac involvements (pericarditis, endocarditis) [2]. Because of the systemic nature of the illness, increased pigmentation of skin, polyarthritis, ascites, hepatomegaly and splenomegaly, pleuritis, ophthalmic (chronic retinitis and uveitis) or central nervous system involvements (dementia, ophthalmoplegia, paralysis of gaze, myoclonus or cerebella ataxia) are also seen $[1,3,4]$.

Received 4 July 1996; revised version accepted 20 Sept. 1996.

Corresponding author: Dr C. Dauga.
Histological diagnosis is usually by microscopic examination of the duodenal lamina propria. Large macrophages that contain positive periodic acid-Schiff (PAS) inclusions are observed [5]. PAS-positive granulations are sickle-shaped and brilliantly purplered (magenta) in colour. These characteristic cells were first described as sickle-particle-containing (SPC) cells [6]. The irregular aggregates responsible for PAS-positivity of macrophages are glycoproteins, probably derived from degenerate bacterial membranes [7]. These aggregates are generally considered sufficient for a diagnosis of Whipple's disease in the intestinal bowel.

However, histological diagnosis poses many problems. Histologically, AIDS cases with Mycobacterium avium-intracellulare bowel lesions resemble Whipple's disease [8]. Differentiation is by acid-fast staining which is positive for Mycobacterium and negative for Whipple's disease agent [9]. Corynebacterium spp. and Rhodococcus equi infections also mimic the histological aspect of Whipple's disease by the presence of PAS-positive inclusions in macrophages $[2,10]$. In extra-intestinal tissue, the typical 
lesion is more difficult to observe [2]. Peripheral lymph nodes show less intense PAS-positive reactions than SPC cells [11]. PAS-positive macrophages can also be seen in other diseases, and these changes are not considered to be of diagnostic value [12]. Synovial fluid smears show PAS-positive material in both polymorphonuclear and synovial cells similar to that observed in other inflammatory arthropathies [13]. Furthermore, the beginning of Whipple's disease may mimic sarcoidosis with polyvisceral granulomatous dissemination. Whipple's disease-specific SPC cells appear later [4, 12, 14].

The atypical intestinal histology and diagnostic problems of extra-intestinal Whipple's disease [1518] are good reasons to look for other diagnostic methods. Electron microscopy can help in identifying macrophage inclusions. These are heterophagic vacuoles containing fragments of bacterial cell walls. The ultrastructural pattern of the rod-shaped wall corresponds to that of gram-positive bacteria with an additional trilamellar membrane external to the cell wall, specific to the Whipple's disease bacillus [7, 19, 20]. Unfortunately, this technique is not available in all laboratories.

No bacterium has been isolated reproducibly from Whipple's disease lesions by classical bacteriological methods. Occasionally, unidentified Corynebacterium spp. or Streptococcus spp. have been isolated [2]. New methods able to detect and identify bacteria without culture have been proposed [21]. PCR has been used to amplify bacterial $16 \mathrm{~S}$ rRNA genes (rDNA) from infected tissues of patients with Whipple's disease. From the novelty of the 16S rDNA sequence, the bacillus was named Tropheryma whippelii and two specific PCR primers have been described [22, 23]. PCR has detected $T$. whippelii sequences in duodenal mucosa [16, 24-27], peripheral blood [24, 28], bone marrow [26], cells derived from pleural effusion [24], vitreous tissue [16] and aortic valve tissue [29].

As infections caused by the $M$. avium complex, Corynebacterium spp. and $R$. equi may be syndromes or have histopathology similar to Whipple's disease, this paper describes a new approach for identification of suspected Whipple's disease. This strategy initially amplifies the 16S rDNA of gram-positive bacteria with a high $\mathrm{G}+\mathrm{C}$ content directly and specifically from clinical specimens. Assays were performed with typical digestive Whipple's disease specimens as well as neurological or rheumatological cases. When this initial amplification was negative, universal primers were used in repeat experiments. In both cases, the 16S rDNA amplicon was sequenced and compared with 16S rRNA sequences available in databases. Identification was achieved when the specimen sequence was identical with one from the databases. Otherwise, the unknown sequence was positioned on the phylogenetic tree. Taking into account the initial amplification results, a nested amplification method was devised for the detection of any gram-positive bacterium and the specific identification of $T$. whippelli in order to speed identification and reduce labour associated with DNA sequencing.

\section{Materials and methods}

\section{Bacterial strains}

To evaluate the specificity of the PCR, genomic DNA extracts from the following bacteria, representing the major subdivisions of the Eubacteria [30], were used as controls: Terrabacter tumescens strain CIP 102515; Rothia dentocariosa strain CIP 8183; Arthrobacter globiformis strain CIP 8184; Micrococcus luteus strain CIP A270; Corynebacterium xerosis strain ATCC 373; Propionibacterium acnes strain ATCC 6919; Gardnerella vaginalis; Mycobacterium avium (high $\mathrm{G}+\mathrm{C}$ gram-positive branch); Staphylococcus aureus; Bacillus cereus (low G + C gram-positive branch); Afipia felis strain ATCC 53690 (Proteobacteria $\alpha$ subgroup); Alcaligenes faecalis; Burkholderia cepacia (Proteobacteria $\beta$ subgroup); Escherichia coli strain K12; Salmonella enterica; Pseudomonas aeruginosa (Proteobacteria $\gamma$ subgroup) Helicobacter pylori (Proteobacteria $\varepsilon$ subgroup) and Bacteroides fragilis (Flavobacterium phylum).

R. dentocariosa was grown on Columbia Agar (Diagnostics Pasteur, Marnes-la-Coquette, France) supplemented with defibrinated horse serum 20\% $\mathrm{v} / \mathrm{v}$ and incubated at $37^{\circ} \mathrm{C}$. A. globiformis, Ter. tumescens and $M$. luteus were grown on Columbia Agar at $20^{\circ} \mathrm{C}, 25^{\circ} \mathrm{C}$ and $30^{\circ} \mathrm{C}$, respectively. All other species were grown on Tryptocasein Soya Agar (Diagnostics Pasteur) at $30^{\circ} \mathrm{C}$.

\section{Clinical specimens}

Whipple's disease was suspected on the basis of clinical or histopathological features, or both. Specimens consisting of non-fixed frozen biopsies of fundus, ileum or jejunum, mesenteric lymph node, cerebrospinal or articular fluid were received from 10 different patients with suspected Whipple's disease (Table 1). Clinical presentations were variable. Six patients (cases 1-6) had gastritis, duodenal lesions or jejuno-colitis, associated with weight loss, abdominal pain and fever. Case 5 and case 6 [31] had arthritis, in one instance on prosthetic material, complicating a diagnosis of Whipple's disease. Cases 7, 8, 9 [32] and 10 had suspected neurological Whipple's disease without gastrointestinal symptoms. PAS-positive macrophages in the endoscopic biopsies had been seen only in cases 1, 5 and 7 (Table 1). Ten other specimens from patients with no evidence of Whipple's disease were included as negative controls. These specimens consisted of two diarrhoeal stools, two hepatic biopsies (with granulomatous lesions), five gastric biopsies (with gastritis) and one sample of articular fluid. 
Table 1. Clinical specimens from suspected cases of Whipple's disease and results obtained following examination by different PCR methods

\begin{tabular}{|c|c|c|c|c|c|c|}
\hline \multirow[b]{2}{*}{$\begin{array}{l}\text { Case } \\
\text { no. }\end{array}$} & \multirow[b]{2}{*}{ Specimen } & \multirow{2}{*}{$\begin{array}{l}\text { PAS-stained } \\
\text { granulations } \\
\text { in intestinal } \\
\text { macrophages }\end{array}$} & \multicolumn{2}{|c|}{$\begin{array}{l}\text { Identification following } \\
\text { amplification and sequencing }\end{array}$} & \multicolumn{2}{|c|}{$\begin{array}{l}\text { Identification following } \\
\text { nested PCR }\end{array}$} \\
\hline & & & $\begin{array}{c}\text { High } \mathrm{G}+\mathrm{C} \text { gram-positive } \\
\text { primers }\end{array}$ & $\begin{array}{l}\text { Universal } \\
\text { primers }\end{array}$ & $\begin{array}{l}\text { Gram-positive } \\
\text { primers }\end{array}$ & $\begin{array}{c}\text { T. whippelii-specific } \\
\text { primers }\end{array}$ \\
\hline 1 & Intestinal biopsy & + & T. whippelii & ND & + & T. whippelii \\
\hline 2 & Intestinal biopsy & - & Corynebacterium spp. & ND & + & - \\
\hline 3 & Intestinal biopsy & - & negative & Enterococcus spp. & + & - \\
\hline 4 & Intestinal biopsy & - & ND & ND & - & - \\
\hline 5 & Intestinal biopsy & + & ND & ND & + & T. whippelii \\
\hline 6 & Articular fluid & - & ND & ND & + & T. whippelii \\
\hline 7 & Intestinal biopsy & + & ND & ND & - & - \\
\hline 8 & Intestinal biopsy & - & Negative & Enterobacteriaceae & - & - \\
\hline 9 & Cerebrospinal fluid & - & ND & ND & + & T. whippelii \\
\hline 10 & Cerebrospinal fluid & - & ND & ND & - & - \\
\hline
\end{tabular}

$\mathrm{ND}$, not done.

\section{DNA extraction}

Genomic DNA was extracted from bacteria or clinical samples with a procedure used previously for studying cat scratch disease [33]. A negative control (all the reagents without sample) was included in each batch of experiments to ensure that none of the extraction buffers or reagents was contaminated with target DNA.

\section{$16 S$ rDNA amplification before sequencing}

Reaction mixtures were prepared under semi-sterile conditions following published guidelines to avoid contamination [34]. PCR amplification (see below) was performed with a DNA Thermal Cycler Model 480 (Perkin Elmer). A blank control without template DNA was included in each batch of experiments and yielded no PCR product, demonstrating that contamination was not a problem. DNA extracted from $C$. xerosis was used as a positive control.

The following oligonucleotide primers were selected on the basis of 16S rDNA sequence conservation among 83 sequences (obtained from GenBank) of gram-positive bacteria with a high $\mathrm{G}+\mathrm{C}$ content: primer G+, 5'-ACGGGTAGCCGGCCTGAGAGGG3'; and primer $\mathrm{rG}+, 5^{\prime}$-ACCCCGTCAATTYCTTTGAGTTTTAG-3' (Y=C or T). The target of primer G+ was located at position 290 and the target of primer $\mathrm{rG}+$ was located at position 920 (E. coli numbering system [35]). For $16 \mathrm{~S}$ rDNA amplification before sequencing, Bio-Taq Polymerase (Bioprobe, Montreuil-sous-bois, France) was used, with a predenaturation step of $5 \mathrm{~min}$ at $94^{\circ} \mathrm{C}$, followed by 35 cycles of $94^{\circ} \mathrm{C}$ for $1 \mathrm{~min}, 70^{\circ} \mathrm{C}$ for $1 \mathrm{~min}$ and $72^{\circ} \mathrm{C}$ for $1 \mathrm{~min}$. For elongation of PCR product, a final step at $72^{\circ} \mathrm{C}$ for $5 \mathrm{~min}$ was included.

To examine whether gram-positive bacteria with a high $\mathrm{G}+\mathrm{C}$ content were the only bacteria associated with Whipple's disease, broad-range eubacterial oligonucleotide primers were used [36]. The target of the 5 -end primer was located at position 10 of the $16 \mathrm{~S}$
rDNA gene, and the 3 '-end primer at position 1490 for the same gene. Amplification involved predenaturation for $5 \mathrm{~min}$ at $94^{\circ} \mathrm{C}$, followed by 35 cycles of $94^{\circ} \mathrm{C}$ for $1 \mathrm{~min}, 49^{\circ} \mathrm{C}$ for $1 \mathrm{~min}$ and $72^{\circ} \mathrm{C}$ for $1 \mathrm{~min}$, with a final elongation step at $72^{\circ} \mathrm{C}$ for $5 \mathrm{~min}$. These primers were also used to demonstrate the absence of inhibitors in clinical specimens (stools and gastric biopsies) used as negative controls.

Amplification products were detected by electrophoresis on agarose $0.8 \% \mathrm{w} / \mathrm{v}$ gels in Tris-acetate buffer (0.04 M Tris-acetate, $0.002 \mathrm{M}$ EDTA, pH 8.1), with a 1-kb DNA Ladder (Gibco BRL) as the DNA size standards.

\section{$16 S$ rDNA cloning and sequencing}

To facilitate cloning, a 12-base dUMP-containing sequence-CUACUACUACUA - was added to the $5^{\prime}$ end of PCR primers [37]. The resulting PCR product was cloned in plasmid pAMP1 with the CLONAMP ${ }^{\mathrm{TM}}$ System (Gibco BRL). Twelve clones/specimen were chosen for amplification in E. coli strain MC1061. The presence of the insert was verified by restriction digestion with Bam HI and EcoRI [38]. Two clones/ specimen were sequenced by 'cycle sequencing' (Amersham International) with universal primers complementary to plasmid or conserved regions of 16S rDNA labelled with $\left[\gamma \mathrm{P}^{33}\right]$-ATP (Isotopchim, Ganagobie-Peyruis, France) [39].

\section{Phylogenetic interpretation}

Partial sequences obtained were compared with rRNA sequences from the GenBank (Bethesda, MD, USA) and European Molecular Biology Laboratory (Cambridge) databases provided with the Lasergene software (DNAstar, London). If no sequence was identical, the nearest sequences were aligned manually. Identification of the partial sequence was performed with phylogenetic analysis by the Maximum Parsimony Method with the PAUP program (heuritic option) [40] and by 
the Distance Method with the Kimura parameters [41] included in the programs DNADIST and NEIGHBOR [42] contained in the PHYLIP Inference Package [43].

\section{Nested PCR for diagnosis}

16S rDNA from the gram-positive phylum was amplified with Hi-Taq Polymerase (Bioprobe). Primer $A_{L}-$ 5'-AGRGTTYGATYCTGGCTCAGGAYG- $3^{\prime} \quad(\mathrm{R}=\mathrm{A}$ or G)-was selected on the basis of sequence conservation in the gram-positive phylum of Eubacteria (both low and high $\mathrm{G}+\mathrm{C}$ content organisms in the gram-positive bacteria branch), and had a target at the 5 '-end, position 10, of the 16S rRNA gene. The second primer was $\mathrm{rG}+$ (see above), but was used in this experiment at low stringency $\left(65^{\circ} \mathrm{C}\right)$. Amplification involved predenaturation at $94^{\circ} \mathrm{C}$ for $5 \mathrm{~min}$, followed by 35 cycles of $94^{\circ} \mathrm{C}$ for $1 \mathrm{~min}, 65^{\circ} \mathrm{C}$ for $1 \mathrm{~min}$ and $72^{\circ} \mathrm{C}$ for $1 \mathrm{~min}$, with a final elongation step at $72^{\circ} \mathrm{C}$ for $5 \mathrm{~min}$.

DNA extracts from the strains listed above were used as positive or negative controls. One sample known to contain T. whippelii 16S rDNA sequences (case 1) was included as a control. When no amplification was detected, or when a 'blur' was seen on the agarose gel, the amplification was interpreted as being inhibited by compounds found in the sample. The PCR was then repeated with a sample diluted 10- and 100 -fold.

Depending on the amount of gram-positive 16S rDNA product amplified, the nested PCR was done with $1 \mu 1$ of either a 1 in 10 or 1 in 100 dilution of the initial PCR product. Two internal oligonucleotide primers were used to identify $T$. whippelii. These were primer W185-5'-CGACCCATGAGGGCATCCTC-3' (position 185)-and primer rW830-5'-GCGGTGGAACCACCCCCACG-3' (position 830). Nested PCR was performed with predenaturation at $94^{\circ} \mathrm{C}$ for $5 \mathrm{~min}$, followed by 35 cycles of $94^{\circ} \mathrm{C}$ for $1 \mathrm{~min}, 60^{\circ} \mathrm{C}$ for $1 \mathrm{~min}$ and $72^{\circ} \mathrm{C}$ for $1 \mathrm{~min}$. The amplified products were detected by electrophoresis as described above.

The resulting amplification products were checked by digestion with AvaII, StuI or Pst I. These enzymes cleave $T$. whippelii $16 \mathrm{~S}$ rDNA at position 625 with AvaII, 489 with Pst I and 415 with StuI, yielding products of specific sizes. 16S rDNA of phylogenetically related species (Ter. tumescens, Dermatophilus congolensis, Clavibacter xyli, $R$. dentocariosa, $A$. globiformis, $M$. luteus) have different cleavage sites on the corresponding rDNA fragment, resulting in restriction fragments of different sizes. Therefore, $10 \mu \mathrm{l}$ of each PCR amplification product were digested, according to the conditions recommended by the manufacturer of the enzymes (New England Biolabs), and analysed by electrophoresis on an agarose (Bioprobe) $1 \% \mathrm{w} / \mathrm{v}$ gel containing NuSieve Agarose (FMC Bio Products, Rockland, ME, USA).

\section{Results}

\section{$16 S$ rRNA gene sequence analysis}

PCR amplification with primers $\mathrm{G}+$ and $\mathrm{rG}+$ and either $C$. xerosis DNA or DNA extracts from cases 1 and 2 yielded a 630 -bp fragment. No PCR product was observed with a control containing no DNA template or DNA extracts from cases 3 and 8 (data not shown). The 630-bp fragments amplified from the two clinical cases were cloned and sequenced. For case 1, the sequence obtained was identical to that of T. whippelii 16S rDNA (accession no. 87484 [23]) (Table 1). For case 2, the sequence obtained corresponded to a Corynebacterium spp. 16S rDNA, (Fig. 1). On this part of the 16S rRNA, the sequence was identical to those of $C$. amycolatum and $C$. asperum.

PCR amplification with eubacterial primers applied to DNA extracts from both of the negative samples yielded a 1480-bp product. These fragments were cloned and partially sequenced. One sequence belonged to a member of the Enterobacteriaceae (case 8 ), while the other was related to sequences belonging to members of the genus Enterococcus (case 3).

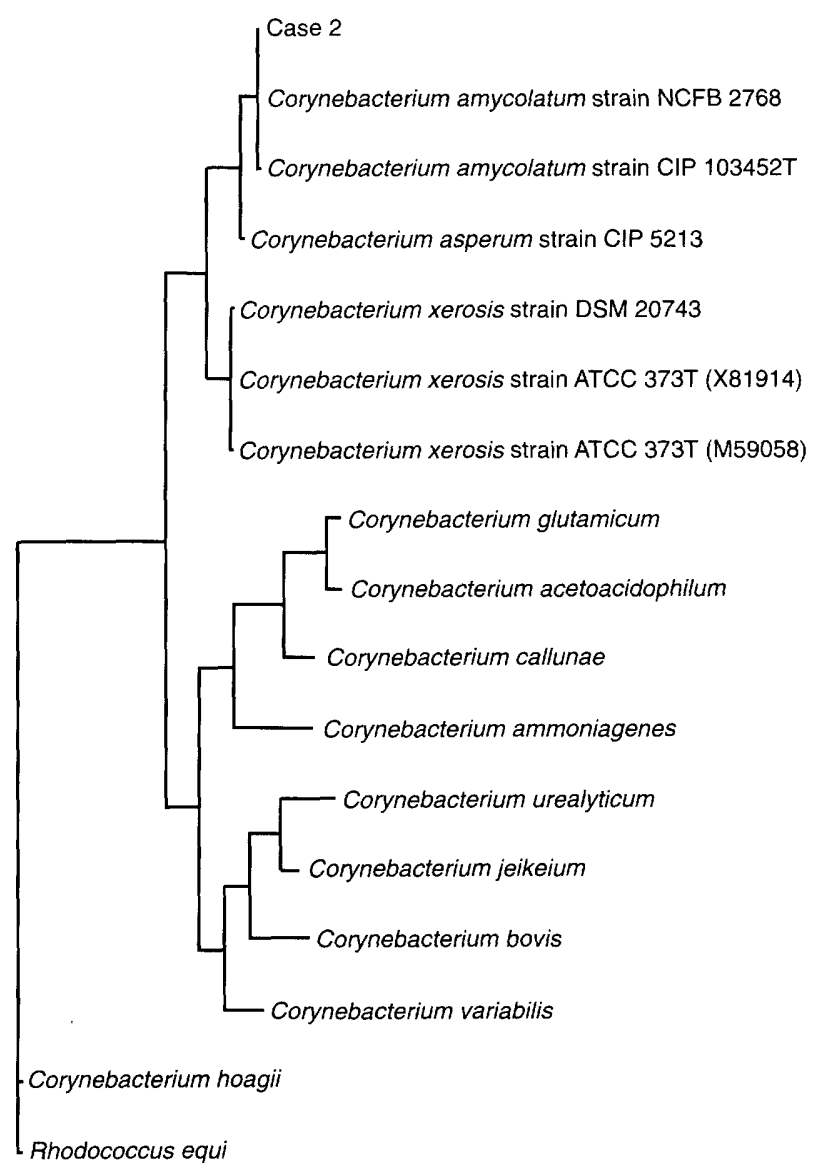

Fig. 1. Phylogenetic tree derived from a comparison of the 16S rDNA sequences of Corynebacterium spp. by the PAUP method. GenBank accession numbers are in parentheses. The position of the sequence derived from case 2 is indicated. 
Nested $P C R$ and restriction fragment length polymorphisms (RFLPS)

The nested amplification method was tested with the 10 clinical samples (including case 1, shown above to contain 16S rDNA corresponding to T. whippelii, and case 2 , shown to contain the $16 \mathrm{~S}$ rDNA sequence of a Corynebacterium spp.), all the bacteria listed in Materials and methods, and 10 negative control clinical specimens. A 910-bp fragment was obtained after the first amplification with primers $A_{L}$ and $\mathrm{rG}+$ (specific for gram-positive bacteria) with $S$. aureus, B. cereus, C. xerosis (Fig. 2, lane 6), P. acnes (lane 7), A. globiformis (lane 8), Ter. tumescens (lane 9), $R$. dentocariosa, M. avium, G. vaginalis, Mic. luteus, the stools and gastric biopsies used as control specimens, and five clinical samples (cases 1, 2, 3, 5 and 9). No amplification product was observed for Af. felis, Alc. faecalis, E. coli (lane 10), Sal. enterica, Ps. aeruginosa, Bur. cepacia, H. pylori, Bact. fragilis (lane 11), the negative control (all the reagents without target DNA), the hepatic biopsies and articular fluid used as control specimens, and the other clinical samples (cases 4, 6, 7, 8 and 10) (lanes 4 and 5). Inhibition, evidenced by a 'blur' on the agarose gel, was detected with three samples. Sample dilution allowed subsequent amplification of gram-positive 16S rDNA from case 6 (lane 3).

The second amplification (with T. whippelii-specific primers W185 and rW830) performed on the 910-bp amplicon generated a 650-bp fragment for four clinical samples: cases 1 (Fig. 3, lane 12), 5, 6 (containing inhibitors) and 9. No amplification was obtained with all the other strains or samples tested: S. aureus, G. vaginalis, B. cereus. M. avium (Fig. 3, lane 1), C. xerosis (lane 2), P. acnes (lane 3), $A$. globiformis (lane 4), Ter. tumescens (lane 5), $R$. dentocariosa (lane 6), E. coli (lane 7), Bact. fragilis (lane 8), the negative control (lane 15), and the five clinical samples corresponding to cases $3,4,7,8$ and 10 (lanes 9, 10, 11 and 13). For case 2, containing Corynebacterium spp. 16S rDNA (lane 14), a 910-bp fragment resulting from the first amplification persisted on the agarose gel, but no 650-bp fragment was seen.

The RFLP pattern of the products, generating two fragments of $300 \mathrm{bp}$ and $350 \mathrm{bp}$ with Pst I (Fig. 4, lane 1), two fragments of $235 \mathrm{bp}$ and $415 \mathrm{bp}$ with Stu I (Fig. 4, lane 5), and two fragments of $220 \mathrm{bp}$ and $430 \mathrm{bp}$ with AvaII (data not shown) were used to confirm $T$. whippelii $16 \mathrm{~S}$ rDNA sequence identity.

Of the 10 samples from suspected cases of Whipple's disease, six contained $16 \mathrm{~S} \mathrm{rDNA}$ of gram-positive bacteria. Only four $16 \mathrm{~S}$ rDNA sequences corresponded to $T$. whippelii (Table 1). For the six patients with gastrointestinal symptoms, only three samples (from three patients) contained detectable T. whippelii 16S rDNA. Of the three samples containing bowel PAS-positive macrophages, two contained detectable T. whippelii $16 \mathrm{~S}$ rDNA. Surprisingly, of four suspected cases of neurological Whipple's disease, T. whippelii

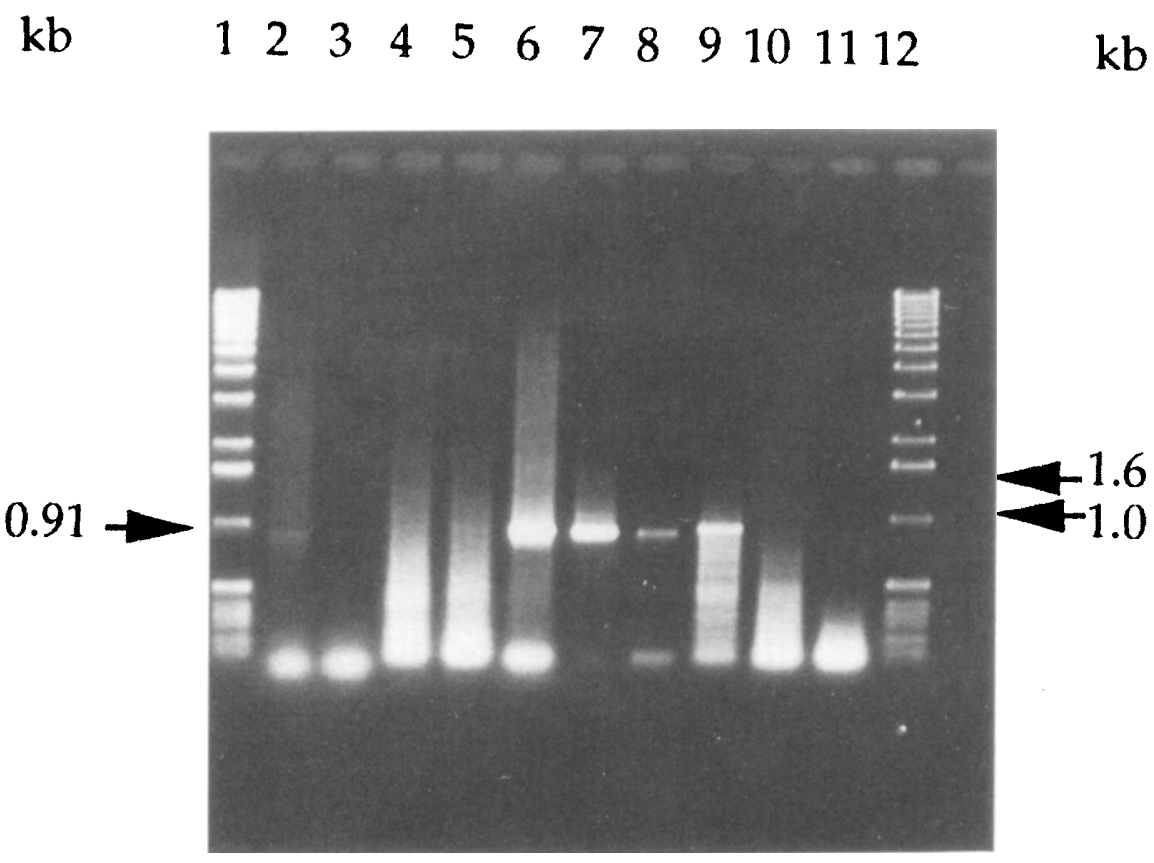

Fig. 2. PCR products derived from specific amplification of $16 \mathrm{~S}$ rDNA gene fragments of the gram-positive phylum. DNA samples were: lane 1, DNA size markers; 2, Whipple's disease specimen (case 1) with rDNA sequence corresponding to $T$. whippelii; 3, Whipple's disease suspected specimen (case 7); 4, Whipple's disease suspected specimen (case 5); 5, Whipple's disease suspected specimen (case 4); 6, C. xerosis; 7, P. acnes; 8, A. globiformis; 9 , Ter. tumescens; 10, E. coli; 11; Bact. fragilis; 12, DNA size markers. 


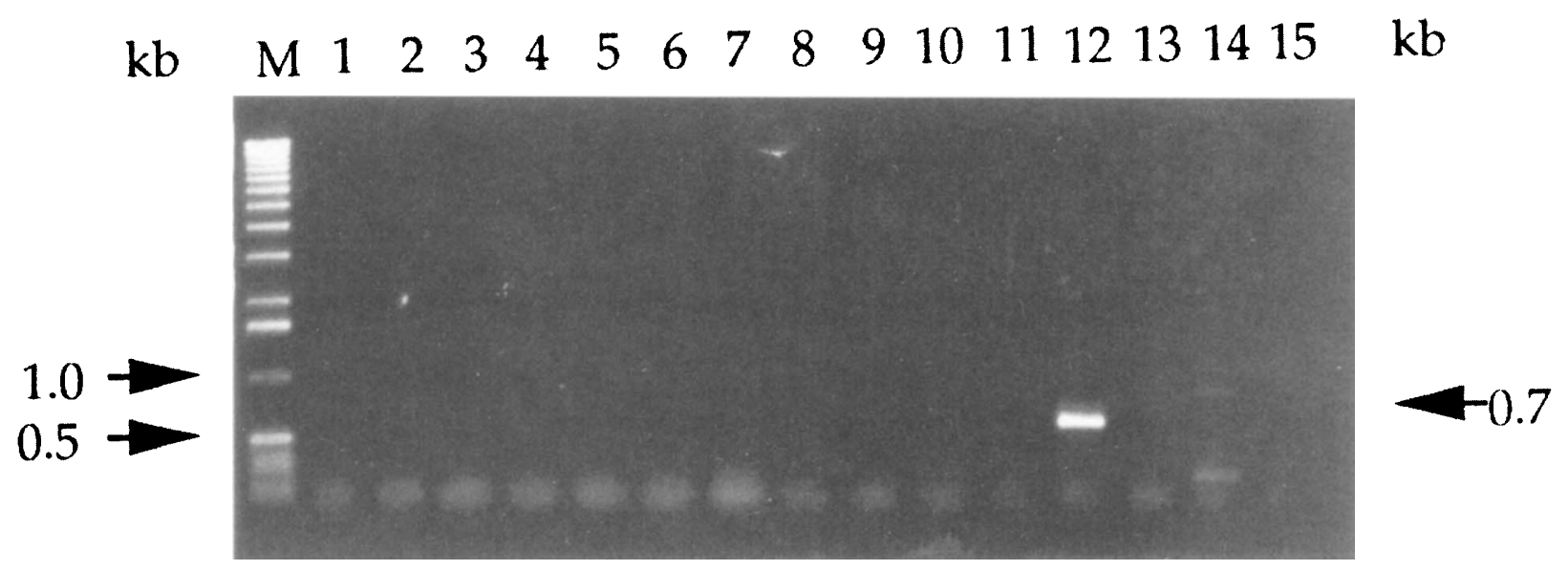

Fig. 3. PCR products derived from specific amplification of $16 \mathrm{~S}$ rDNA gene fragments of $T$. whippelii. DNA samples were: lane M, DNA size markers; 1 , M. avium; 2, C. xerosis; 3, P. acnes; 4 , A. globiformis; 5, Ter. tumescens; $\mathbf{6}$, R. dentocariosa; 7, E. coli; $\mathbf{8}$, Bact. fragilis; 9, sample from case $5 ; \mathbf{1 0}$, sample from case $8 ; \mathbf{1 1}$, sample from case 4; 12, Whipple's disease specimen (case 1) with rDNA sequence corresponding to $T$. whippelii; $\mathbf{1 3}$, sample from case $3 ; \mathbf{1 4}$, Whipple's disease suspected specimen (case 2 ) with rDNA sequence corresponding to $C$. xerosis; 15 , negative control.

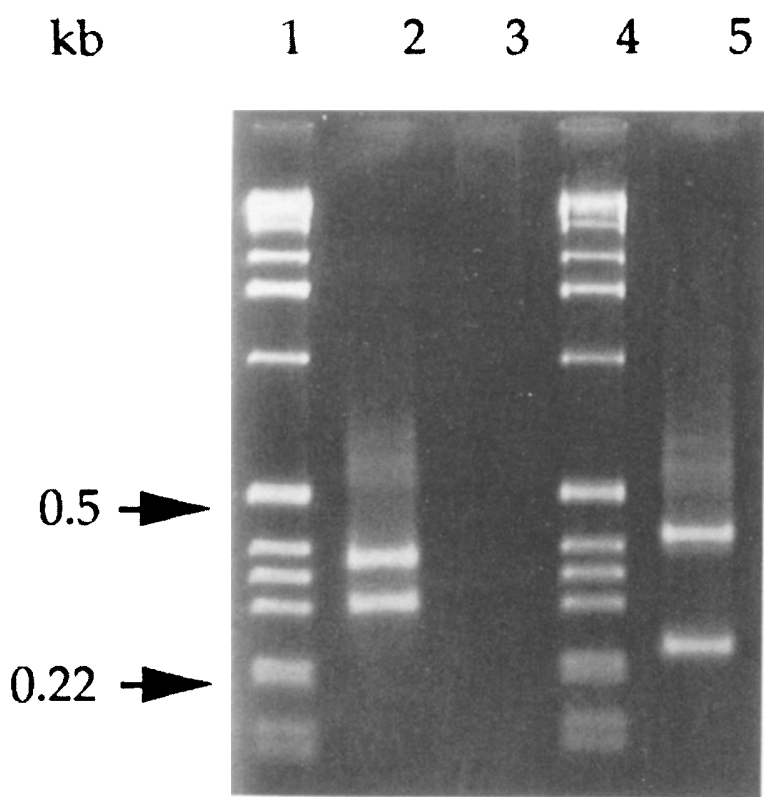

Fig. 4. Restriction digest profiles following specific amplification of $16 \mathrm{~S}$ rDNA gene fragments from $T$. whippelii. Lane 1, DNA size markers; 2, Pst I digest; 3, no sample; 4, DNA size markers; 5, Stu I digest.

16S rDNA was detected in the cerebrospinal fluid of only one case. In addition, $T$. whippelii $16 \mathrm{~S}$ rDNA was amplified from the articular fluid of one patient with arthritis complicating a diagnosis of Whipple's disease.

\section{Discussion}

The identification strategy used in this paper was based on the current hypothesis that Whipple's disease is caused by a gram-positive bacterium. A first approach detected high $\mathrm{G}+\mathrm{C}$ content gram-positive bacterial
16S rDNA by amplification and sequenced the amplicon to reach identification. A second approach amplified 16S rDNA from any gram-positive bacterium in the clinical specimens and then used the amplicon as a target for a further $T$. whippelii-specific amplification. This nested PCR should be easier to perform than sequencing in clinical laboratories. The small set of cases investigated provided information on the diagnostic ability of these assays.

When clinical signs included diarrhoea, weight loss, abdominal pain, fever and adenopathy, the diagnosis of Whipple's disease made by the physician in charge was confirmed by the detection of $T$. whippelii 16S rDNA (cases 1, 5 and 6). However, with clinically atypical disease (case 7), PAS granulations in intestinal macrophages could not be explained by the presence of gram-positive bacteria. In case 2 , the partial $16 \mathrm{~S}$ rDNA sequence was identical to the corresponding $C$. amycolatum and $C$. asperum sequences. These two organisms constitute a single genomic species [44] and seem to be the Corynebacterium species isolated most frequently from clinical infections [45]. Their 16S rDNA sequence could be easily differentiated (10 differences) from the $16 \mathrm{~S}$ rDNA sequence of $C$. xerosis. Thus, the origin of the sequence detected was not a result of laboratory contamination by the $C$. xerosis sequence used as a PCR control. Unidentified Corynebacterium spp. and $C$. bovis have been reported from suspected cases of Whipple's disease [2, 46]. However, because the histology of case 2 was not convincing, the sequence obtained may still originate from cutaneous bacteria. Broad-range eubacterial primers occasionally amplified enterobacterial or Enterococcus sequences from negative samples, but these bacteria were not linked to Whipple's disease and probably originated from the intestinal flora. Diagnoses of ischaemic colitis and 
sarcoidosis were made, respectively, for cases 3 and 8 . None of the specimens studied contained $R$. equi or mycobacterial sequences.

When arthritis was the dominant clinical feature, diagnosis was by PCR assay of the gastrointestinal biopsy (case 5) or of the articular fluid (case 6) [31]. Both cases were arthritis relapses which appeared during treatment. In optical microscopy, synovial fluid smears indicated non-specific arthropathy. Detection of Whipple's bacillus by PCR assay can be an alternative to examination of the synovial membrane by electron microscopy [13]. Neurological Whipple's disease was suspected if there was an association of ophthalmoplegia, dementia and cerebella ataxia. Meninges are rarely involved in Whipple's disease, but the presence of typical PAS-positive macrophages has been noted occasionally $[3,47]$. T. whippelii $16 \mathrm{~S}$ rDNA was detected in the cerebrospinal fluid of case 9 only. Reversal of neurological signs and magnetic resonance images by trimethoprim-sulphamethoxazole treatment was in agreement with this diagnosis [32, 47]

In both cases 6 and 9, the duodenum showed no histological evidence of infection and $T$. whippelii $16 \mathrm{~S}$ rDNA was found at other locations. The intestinal tract could either be free from Whipple's bacillus at the start of the disease or the bacteria could be present in insufficient numbers to be observed microscopically or not yet degraded by macrophages [7]. For arthritis without typical intestinal lesions [15], or neurological symptoms without gastrointestinal involvement [48, 49], we recommend that the PCR test be performed with articular or cerebrospinal fluid.

Detection and identification of fastidious pathogenic bacteria has traditionally been a challenge to the clinical microbiologist. When bacteria are non-cultivable, or only cultivable at very low efficiency, amplification and sequencing of rDNA seems to be the best approach. Universal primers can be used to amplify 16S rDNA from unknown bacteria causing infectious diseases and then sequenced [23, 50, 51]. However, when several species occur in the specimen, separation of the various DNA sequences by cloning is necessary, which makes the procedure laborious. A major interpretation problem arises when a sequence corresponding to a ubiquitous cutaneous, intestinal, or environmental species is found.

Specific primers for PCR amplification of $T$. whippelii rDNA have been described previously [23], but were not used in this study for the following reasons. Although the implication of T. whippelii in Whipple's disease is quite convincing, the occasional implication of other gram-positive bacteria has not been ruled out. Furthermore, M. avium-intracellulare, Corynebacterium spp. and $R$. equi have been found to generate PAS-positive macrophages in intestinal lesions. Amplification of sequences from high $\mathrm{G}+\mathrm{C}$ gram- positive bacteria or, for practical reasons, grampositive sequences in general, would be less likely to miss taxonomically related bacteria possibly associated with the patient's disease. Lack of initial amplification could be followed by the use of universal primers (subject to the caveats discussed above).

Identification of the PCR product was by sequencing or by $T$. whippelii-specific amplification. For bacteria that have been identified only on the basis of their $16 \mathrm{~S}$ rRNA, the sequencing procedure is necessary to validate the specificity of the primers. This kind of strategy limits contamination risks and reduces tedious clone screening procedures. When $T$. whippelii-specific amplification was performed to identify the grampositive 16S rDNA PCR product, the target for the amplification was chosen to allow a confirmative restriction digestion of the second amplicon. This nested PCR had a better sensitivity and specificity than a simple PCR. When $T$. whippelii-specific amplification fails, the first amplicon should be sequenced and the sequence compared with databases. We propose that such a strategy should be used for the detection of bacteria associated with Whipple's disease.

We thank M. Vergnaud (Caen); S. Loulier, A. Audebert and J. H. Barrier (Nantes); A. Fresard and A. Ros (Saint-Etienne); S. Alain and A. Lavergne (Lariboisière, Paris); J. C. Rambaud (Saint-Lazare Paris); P. Cacoub, L. Cohen and P. Godeau (Pitié-Salpétrière, Paris); and P. D. Molyneux (National Hospital for Neurology and Neurosurgery, London) for providing clinical samples. We also thank C. Bizet for the type strains, J. D. Poveda for negative clinical controls and M. Huerre for helpful discussion.

\section{References}

1. Dobbins WO. Whipple's disease. Springfield, Charles C Thomas, 1987.

2. Maizel H, Ruffin JM, Dobbins WO. Whipple's disease: a review of 19 patients from one hospital and a review of the literature since 1950. Medicine (Baltimore) 1970; 49: 175-205.

3. Feurle GE, Volk B, Waldherr R. Cerebral Whipple's disease with negative jejunal histology. $N$ Engl $J$ Med 1979; 300 907-908.

4. Relman AD. Whipple's disease. In: Blaser MJ, Smith PD, Ravdin JI, Greenberg HB, Guerrant RL (eds) Infections of the gastrointestinal tract. New York, Raven Press 1995: 919-936.

5. Black-Schaffer B. The tinctorial dernonstration of a glycoprotein in Whipple's disease. Proc Soc Exp Biol Med 1949; 72 $225-227$.

6. Sieracki JC, Fine G. Whipple's disease: observations on systemic involvement. II. Gross and histologic observations. Arch Pathol 1959; 67: 81-93.

7. Silva MT, Macedo PM, Nunes JFM. Ultrastructure of bacill and the bacillary origin of the macrophagic inclusions in Whipple's disease. J Gen Microbiol 1985; 131: 1001-1013.

8. Strom RL, Gruninger RP. AIDS with Mycobacterium aviumintracellulare lesions resembling those of Whipple's disease. $N$ Engl J Med 1983; 309: 1323-1324

9. Roth RI, Owen RL, Keren DF. AIDS with Mycobacterium avium-intracellulare lesions resembling those of Whipple's disease. $N$ Engl J Med 1983; 309: 1324-1325.

10. Wang HH, Tollerud D, Danar D, Hanff P, Gottesdiener K, Rosen S. Another Whipple-like disease in AIDS? $N$ Engl $J$ Med 1986; 314: 1577-1578. 
11. Upton AC. Histochemical investigation of the mesenchymal lesions in Whipple's disease. Am J Clin Pathol 1952; 22: $755-764$.

12. Rodarte JR, Garrison CO, Holley KE, Fontana RS. Whipple's disease simulating sarcoidosis. A case with unique clinical and histological features. Arch Int Med 1972; 129: 479-482.

13. Hawkins CF, Farr M, Morris CJ, Hoare AM, Williamson N. Detection by electron microscope of rod-shaped organisms in synovial membrane from a patient with the arthritis of Whipple's disease. Ann Rheum Dis 1976; 35: 502-509.

14. Dobbins WO. The diagnosis of Whipple's disease. $N$ Engl $J$ Med 1995; 332: 390-392.

15. Meier J, Berwanger I, Zangana N, Hellerich O. [Whipple disease with negative duodenal histology - a case report and review of the literature.] $Z$ Rheumatol 1994; 53: 357-362.

16. Rickman LS, Freeman WR, Green WR et al. Uveitis caused by Tropheryma whippelii (Whipple's bacillus). $N$ Engl $J$ Med 1995; 332: 363-366.

17. Fantry GT, James SP. Whipple's disease. Dig Dis 1995; 13: $108-118$.

18. Adams M, Rhyner PA, Day J, Dearmond S, Smuckler EA. Whipple's disease confined to the central nervous system. Ann Neurol 1987; 21: 104-108.

19. Yardley JH, Hendrix TR. Combined electron and light microscopy in Whipple's disease. Demonstration of 'bacillary bodies' in the intestine. Bull John Hopk Hosp 1961; 109: 80.

20. Crockett Chears W, Ashworth CT. Electron microscopic study of the intestinal mucosa in Whipple's disease. Demonstration of encapsulated bacilliform bodies in the lesion. Gastroenterologv 1961; 41: 129-138.

21. Chen K, Neimark H, Rumore P, Steinman CR. Broad range DNA probes for detecting and amplifying eubacterial nucleic acids. FEMS Microbiol Lett 1989; 57: 19-24.

22. Wilson $\mathrm{KH}$, Blitchington $\mathrm{R}$, Frothingham R, Wilson JAP. Phylogeny of the Whipple's-disease-associated bacterium. Lancet 1991; 338: 474-475.

23. Relman AD, Schmidt TM, MacDermott RP, Falkow $S$. Identification of the uncultured bacillus of Whipple's disease. $N$ Engl J Med 1992; 327: 293-301.

24. Müller C, Stain C, Burghuber O. Tropheryma whippelii in peripheral blood mononuclear cells and cells of pleural effusion. Lancet 1993; 341: 701.

25. von Herbay A, Ditton HJ, Maiwald M, Meier-Willersen HJ Nachweis von Tropheryma whippelii mit der PolymeraseKettenreaktion vor und nach Therapie eines Morbus Whipple. [Detection of Tropheryma whippelii using the polymerase chain reaction before and after therapy of Whipple's disease.] Dtsch Med Wochenschr 1994; 119: 1679.

26. Riederer J. Alterer patient mit Arthralgien, Fieberschüben, Schwäche und Gewichtsabnahme. [An elderly patient with arthralgia, fever, weakness and weight loss. Diagnosis of Whipple's disease by PCR detection of Tropheryma whippelii.] Fortschr Med 1995; 113: 70-72.

27. Maiwald M, Meier-Willersen HJ, Hartmann M, von Herbay A Detection of Tropheryma whippelii DNA in a patient with AIDS. J Clin Microbiol 1995; 33: 1354-1356.

28. Lowsky R, Archer GL, Fyles G et al. Diagnosis of Whipple's disease by molecular analysis of peripheral blood. $N$ Engl $J$ Med 1994; 331: 1343-1346.

29. Wendler D, Mendoza E, Schleiffer T, Zander M, Maier M. Tropheryma whippelii endocarditis confirmed by polymerase chain reaction. Eur Heart $J$ 1995; 16: 424-425.

30. Woese CR. Bacterial evolution. Microbiol Rev 1987; 51: $221-271$.

31. Frésard A, Guglielminotti C, Berthelot $P$ et al. Prosthetic joint infection caused by Tropheryma whippelii (Whipple's bacillus). Clin Infect Dis 1996; 22: 575-576
32. Cohen L, Berthet K, Dauga C, Thivart L, Pierrot-Deseilligny C. Polymerase chain reaction of cerebrospinal fluid to diagnose Whipple's disease. Lancet 1996; 347: 329.

33. Dauga C, Miras I, Grimont PAD. Identification of Bartonella henselae and $B$. quintana $16 \mathrm{~S}$ rDNA sequences by branch-, genus- and species-specific amplification. $J$ Med Microbiol 1996; 45: 192-199.

34. Sarkar G, Sommer SS. Shedding light on PCR contamination. Nature 1990; 343: 27.

35. Brosius J, Palmer ML, Kennedy PJ, Noller HF. Complete nucleotide sequence of $16 \mathrm{~S}$ ribosomal RNA gene from Escherichia coli. Proc Natl Acad Sci USA 1978; 75: 48014805 .

36. Böttger EC. Rapid determination of bacterial ribosomal RNA sequences by direct sequencing of enzymatically amplified DNA. FEMS Microbiol Lett 1989; 65: 171-176.

37. Rashtchian A, Buchman GW, Schuster DM, Berninger MS. Uracil DNA glycosylase-mediated cloning of polymerase chain reaction-amplified DNA: application to genomic and cDNA cloning. Anal Biochem 1992; 206: 91-97.

38. Maniatis T, Sambrook J, Fritsch EF, (eds). Molecular cloning: a laboratory manual, 2nd edn. Cold Spring Harbor, New York, Cold Spring Harbor Laboratory. 1989.

39. Blakesley RW. Cycle sequencing. In: Griffin H, Griffin A (eds) Methods in molecular biology, DNA sequencing protocols. Totowa, NJ, Humana Press Inc. 1993: 23.

40. Swofford D. PAUP: phylogenetic analysis using parsimony, version 3.0. Computer program distributed by the Illinois Natural History Survey, Champaign, Illinois, USA. 1990.

41. Kimura M. A simple method for estimating evolutionary rates of base substitutions through comparative studies of nucleotide sequences. J Mol Evol 1980; 16: 111-120.

42. Saitou N, Nei M. The neighbor-joining method: a new method for reconstructing phylogenetic trees. Mol Biol Evol 1987; 4: $406-425$

43. Felsenstein J. PHYLIP - Phylogeny Inference Package (version 3.2). Cladistics 1989 ; 5: 164-166.

44. Ruimy R, Riegel P, Boiron P, Monteil H, Christen R. Phylogeny of the genus Corynebacterium deduced from analyses of small-subunit ribosomal DNA sequences. Int $J$ Syst Bacteriol 1995; 45: 740-746.

45. Funke G, Lawson PA, Bernard KA, Collins MD. Most Corynebacterium xerosis strains identified in the routinc clinical laboratory correspond to Corynebacterium amycolatum. $J$ Clin Microbiol 1996; 34: 1124-1128.

46. Gupta S, Pinching AJ, Onwubalili J, Vince A, Evans DJ, Hogson HJF. Whipple's disease with unusual clinical, bacteriologic, and immunologic findings. Gastroenterology 1986; 90: 1286-1289.

47. Ryser RJ, Locksley RM, Eng SC, Dobbins WO, Schoenknecht $\mathrm{RD}$, Rubin CE. Reversal of dementia associated with Whipple's disease by trimethoprim-sulfamethoxazole, drugs that penetrate the blood-brain barrier. Gastroenterology 1984; 86: $745-752$.

48. Knox DL, Bayless TM, Pittman FE. Neurologic disease in patients with treated Whipple's disease. Medicine 1976; 55: $467-476$.

49. Tan TQ, Vogel H, Tharp BR, Carrol CL, Kaplan SL. Presumed central nervous system Whipple's disease in a child: case report. Clin Infect Dis 1995; 20: 883-889.

50. Relman DA, Loutit JS, Schmidt TM, Falkow S, Tompkins LS. The agent of bacillary angiomatosis. An approach to the identification of uncultured pathogens. N Engl J Med 1990; 323: $1573-1580$.

51. Boddinghaus B, Rogall $\mathrm{T}$, Flohr $\mathrm{T}$, Blöcker $\mathrm{H}$, Böttger $\mathrm{E}$. Detection and identification of mycobacteria by amplification of rRNA. J Clin Microbiol 1990; 28: 1751-1759. 